\title{
Components of prolificacy in hyperprolific Large White sows compared with the Meishan and Large White breeds
}

\author{
G. BOLET *(1), Françoise MARTINAT BOTTE**, A. LOCATELLI**, \\ J. GRUAND ***, M. TERQUI **, Françoise BERTHELOT ** \\ *INRA, Station de Génétique quantitative et appliquée \\ F 78530 Jouy-en-Josas \\ **INRA, Station de Physiologie de la Reproduction \\ F 37380 Monnaie \\ ***INRA, Station expérimentale de Sélection porcine \\ F 86480 Rouillé
}

\begin{abstract}
Summary
We identified the most prolific sows in French Large White herds and 17 hyperprolific sows (HLW) were bought whose average litter size on 3 farrowings was 16.5 piglets born alive, i.e. a superiority of 5.3 piglets per litter over their contemporaries. In 1 to 3 subsequent pregnancies we compared ovulation and embryonic mortality rates of $10 \mathrm{HLW}$ with those of 10 Large White (LW) and 7 Meishan (MS) sows. The ovulation rate of HLW was significantly higher than that of LW $(+5.3)$ and MS $(+5.7)$. The ovulation rate of HLW daughters was higher by 2.1 corpora lutea compared to that of LW gilts at the 3rd oestrus after puberty, which occurred at the same age in the 2 genotypes (228 days); MS gilts were pubescent significantly earlier (88 days) and had a significantly lower ovulation rate than both Large White groups. The embryonic mortality rate was high in HLW sows (41 p. 100), whereas that of MS sows was low (16 p. 100), compared to that of LW sows (26 p. 100). Regression of embryonic mortality rate on ovulation rate was significantly positive $(+2.5)$, and embryonic mortality rate remained significantly higher in both Large White groups than in MS sows when corrected for ovulation rate. It is concluded that the improvement of embryonic survival in Large White sows should be a high priority to improve the efficiency of the hyperprolific line and that the Meishan breed which is prolific owing to a low embryonic mortality may be an appropriate experimental model.
\end{abstract}

Key words : Pig breeds, prolificacy, ovulation rate, embryonic mortality.

\section{Résumé}

Composantes de la prolificité de truies Large White hyperprolifiques en comparaison avec des truies de races Meishan et Large White

Les truies les plus prolifiques des élevages français de race Large White ont été recherchées. Dix-sept truies hyperprolifiques (LWH) ont ainsi été achetées, dont la taille de portée moyenne, sur 3 mises bas, était de 16,5 porcelets nés vivants, soit une supériorité

(1) Permanent address : Station d'Amélioration génétique des Animaux, B.P. 27, F 31326 Castanet-Tolosan. 
de 5,3 sur leurs contemporaines. Sur 1 à 3 gestations ultérieures nous avons comparé les taux d'ovulation et de mortalité embryonnaire de 10 truies LWH à ceux de 10 truies Large White (LW) et de 7 truies de race Meishan (MS). Le taux d'ovulation des LWH est significativement supérieur à celui des LW $(+5,3)$ et des MS $(+5,7)$. Chez leurs filles, il est supérieur de 2,1 corps jaunes à celui des LW dès le $3^{\circ}$ cycle après la puberté, qui a lieu à un âge identique (228 jours). Les jeunes truies MS sont pubères plus tôt (à 88 jours) et ovulent significativement moins que les LW aux $1^{\text {er }}$ et $3^{\text {e }}$ cycles. Le taux de mortalité embryonnaire des LWH est très élevé $(41$ p. 100), alors que celui des MS est faible $(16$ p. 100) par rapport à celui des LW $(26 \mathrm{p} .100)$. La régression du taux de mortalité embryonnaire sur le taux d'ovulation est significativement positive $(+2,5)$. Le taux de mortalité embryonnaire corrigé pour le taux d'ovulation reste significativement plus élevé dans les 2 groupes de Large White que chez les MS. Il apparaît donc que l'amélioration génétique du taux de survie embryonnaire chez les truies Large White est un objectif prioritaire pour accroître l'efficacité de la lignée hyperprolifique et que la race Meishan prolifique grâce à une faible mortalité embryonnaire constitue un modèle expérimental privilégié.

Mots clés : Races porcines, prolificité, taux d'ovulation, mortalité embryonnaire.

\section{Introduction}

A national programme for technical management of sow herds gives the opportunity of identifying periodically the most prolific sows in Large White herds. Purchase of sons from those "hyperprolific" sows permitted the creation of a hyperprolific line of boars used for artificial insemination (LEGAULT \& GRUAND, 1976). The components of prolificacy of their daughters were analyzed (LEGAuLT et al., 1981 ; Bolet \& LEGAult, 1982) but, up to now, no information was available about the components of litter size of these hyperprolific sows themselves; on the other hand, it seemed of great interest to compare them to the prolific Chinese breeds studied in France (Legault \& CARITEz, 1983). For these reasons, we purchased from 1981 to 1984 individual hyperprolific Large White sows and compared them and their daughters with Large White and Meishan sows and gilts.

\section{Material and methods}

\section{A. Animals}

The hyperprolific Large White sows (HLW) were identified in herds according to their prolificacy index (I) based on the number of piglets born alive per litter. It was calculated on a maximum of 3 litters, and sows were required to have a score of 110 or more to be selected.

where

$$
I=100+\frac{10 \mathrm{nh}^{2}}{1+(\mathrm{n}-1) \mathrm{r}}(\mathrm{Xt}-\mathrm{Xc})
$$

$\mathrm{n}$ is the number of litters $(1,2$ or 3$)$,

$\mathrm{h}^{2}$ is the heritability of litter size $(=0.10)$,

$r$ is the repeatability of litter size $(=0.15)$,

$\mathrm{Xt}$ is the average litter size of the sow and $\mathrm{Xc}$ the average litter size of the contemporary sows, both corrected for the age of the animal (LEGAULT \& OWEN, 1976). 
A total of 17 HLW sows were bought in 4 groups : 6 in winter 1981-1982, 4 in summer 1982, 4 in summer 1983, 3 in summer 1984. After being purchased, they were housed in the experimental station of Rouillé for a sanitary isolation, where they gave birth to a litter. The 10 sows of the first two groups were then transferred after weaning to the station of physiology of reproduction of Nouzilly to be compared to the Large White sows of this herd (LW) and to Meishan sows (MS) transferred from the experimental herd of Le Magneraud. There were 4 series of comparison of the 3 genotypes. Sows were mated (MS) or inseminated (HLW and LW) by boars of the same genotype at the first oestrus after weaning of the preceding litter. Eight to 10 days after fertilization, the number of corpora lutea on each ovary was counted by endoscopy according to the method of LocATELLI (1971). If the sow returned to service, it was re-examined after another fertilization. The embryonic mortality rate was calculated $a$ posteriori by difference between the number of piglets born (dead plus alive) and the ovulation rate. The age at puberty of daughters of HLW sows of the first group, born in Nouzilly, and contemporary daughters of LW and MS sows was determined by presenting a boar twice each day from 150 days in both Large White groups and from 70 days in MS. They were submitted to an endoscopy during the diestrus phase of the first oestrus and again during the third post-pubertal oestrus to count the number of corpora lutea in both ovaries (ovulation rate).

\section{B. Statistical methods}

Litter size at birth (born alive plus stillborn), ovulation rate (number of corpora lutea in right plus left ovaries) and embryonic mortality rate $(100 \times$ (ovulation rate - litter size)/ovulation rate) of the 3 genotypes were compared with the following analysis of variance model :

where

$$
\mathrm{X}_{\mathrm{ijklm}}=\mu+\mathrm{G}_{\mathrm{i}}+\mathrm{f}_{\mathrm{ij}}+\mathrm{P}_{1}+\mathrm{e}_{\mathrm{ijklm}}
$$

$G_{i}$ is the fixed effect of the genotype (HLW, LW or MS),

$f_{i j}$ is the random effect of the $j$ th sow of the ith genotype,

$S_{k}$ is the fixed effect of the series of comparison $(1,2,3$ or 4$)$,

$P_{1}$ is the fixed effect of the parity divided into 3 groups :

- young sows : 1 st and 2 nd litter,

- adult sows : 3 rd to 5 th litter,

- old sows : 6 th to 8 th litter,

$\mathrm{e}_{\mathrm{ijklm}}$ is the residual $\mathrm{N}\left(\mathrm{O}, \mathrm{S}^{2}\right)$.

The effects of series of comparison and parity were tested by comparison to the residual, the effect of genotype by comparison to the effect of female within genotype. The least squares estimates of genotype effects were compared by Student's t-test.

The regression coefficient of embryonic mortality (EM) on ovulation rate (OR) was calculated by the following analysis of covariance models

$$
\begin{aligned}
& E_{i j}=\mu+G_{i}+b_{i}^{*} O R_{i j}+e_{i j} \\
& E_{i j}=\mu+G_{i}+b^{*} O_{i j}+e_{i j}
\end{aligned}
$$

The age at puberty, ovulation rate at 1 st and 3rd oestrus of daughters of the 3 genotypes were compared by Student's t-test. 


\section{Results}

\section{A. Selection of hyperprolific Large White sows}

Table 1 shows the prolificacy of the 17 HLW sows. Their average within - herd prolificacy index was 112.1 , corresponding to an average litter size of 16.5 piglets born alive. The prolificacy index of 2 sows could not be calculated; their selection was based only on litter size (respectively 38 piglets born alive in 2 litters and 48 in 3 litters).

TABLE 1

Performances of 17 hyperprolific Large White sows.

\begin{tabular}{|c|c|c|c|c|c|}
\hline & $\begin{array}{c}\text { Number } \\
\text { of } \\
\text { observations }\end{array}$ & Mean & $\begin{array}{l}\text { Standard } \\
\text { deviation }\end{array}$ & $\begin{array}{l}\text { Minimum } \\
\text { value }\end{array}$ & $\begin{array}{l}\text { Maximum } \\
\text { value }\end{array}$ \\
\hline $\begin{array}{l}\text { Prolificacy index } \ldots \ldots \ldots \\
\text { based on : }\end{array}$ & 15 (a) & 112.1 & 0.5 & 109 & 115 \\
\hline Litter size (born alive) .. & $47(b)$ & 16.5 & & & \\
\hline-1 st parity $\ldots \ldots \ldots$ & 16 & 15.6 & 0.6 & 13 & 19 \\
\hline - 2nd parity $\ldots \ldots \ldots$ & 15 & 16.5 & 0.5 & 12 & 19 \\
\hline - 3rd parity ........ & 13 & 17.7 & 0.5 & 14 & 20 \\
\hline $\begin{array}{c}\text { Subsequent litter size re- } \\
\text { cords in herd after se- } \\
\text { lection (born alive) } \ldots\end{array}$ & 22 & 14.4 & 0.9 & 5 & 22 \\
\hline
\end{tabular}

(a) The prolificacy index of 2 sows could not be calculated.

(b) For one sow, we knew only the sum of 3 farrowings without details.

\section{B. Comparison of the 3 genotypes}

A total of 27 sows ( $10 \mathrm{HLW}, 10 \mathrm{LW}, 7 \mathrm{MS}$ ) were compared over 1 to 3 farrowings (table 2). The effects associated with series of comparison and parity were not significant for any of the 3 variates analysed (table 3). A significant effect of genotype on ovulation rate $(P<0.01)$ and embryonic mortality rate $(P<0.05)$ was noted (table 3). Ovulation rate of HLW sows was higher than that of $\mathrm{LW}(+5.3 \pm 1.3$, $\mathrm{P}<0.01)$ and MS sows $(+5.7 \pm 1.9, \mathrm{P}<0.01)$. Their embryonic mortality rate was also greater $(+15 \pm 11$ and $+25 \pm 14$ respectively) but those differences were not significant (table 3). The effect of genotype on litter size at birth was not significant, but MS sows exhibited a superiority of $3.6 \pm 1.9$ piglets over LW sows. 


\section{TABLE 2}

Number of observations for each variable by genotype and parity.

\begin{tabular}{|c|c|c|c|c|c|c|c|c|c|}
\hline \multirow{3}{*}{ Genotype } & \multicolumn{9}{|c|}{ Parity } \\
\hline & \multicolumn{3}{|c|}{$1-2$} & \multicolumn{3}{|c|}{$3-4-5$} & \multicolumn{3}{|c|}{$6-7-8$} \\
\hline & $\mathrm{F}$ & O.R. & E.M. & F & O.R. & E.M. & $\mathrm{F}$ & O.R. & E.M. \\
\hline L.W. & 3 & 2 & 2 & 15 & 11 & 10 & 2 & 2 & 1 \\
\hline Hyperprolific L.W. & 0 & 0 & 0 & 7 & 4 & 4 & 18 & 14 & 13 \\
\hline Meishan . . . . . . . . & 10 & 10 & 10 & 5 & 5 & 5 & 1 & 2 & 1 \\
\hline Overall & 13 & 12 & 12 & 27 & 20 & 19 & 21 & 18 & 15 \\
\hline
\end{tabular}

F : Number of litter size records.

O.R. : Number of ovulation rate records.

E.M. : Number of embryonic mortality rate records.

TABLE 3

Results of the analysis of variance and least squares means ( \pm standard deviation) for each genotype.

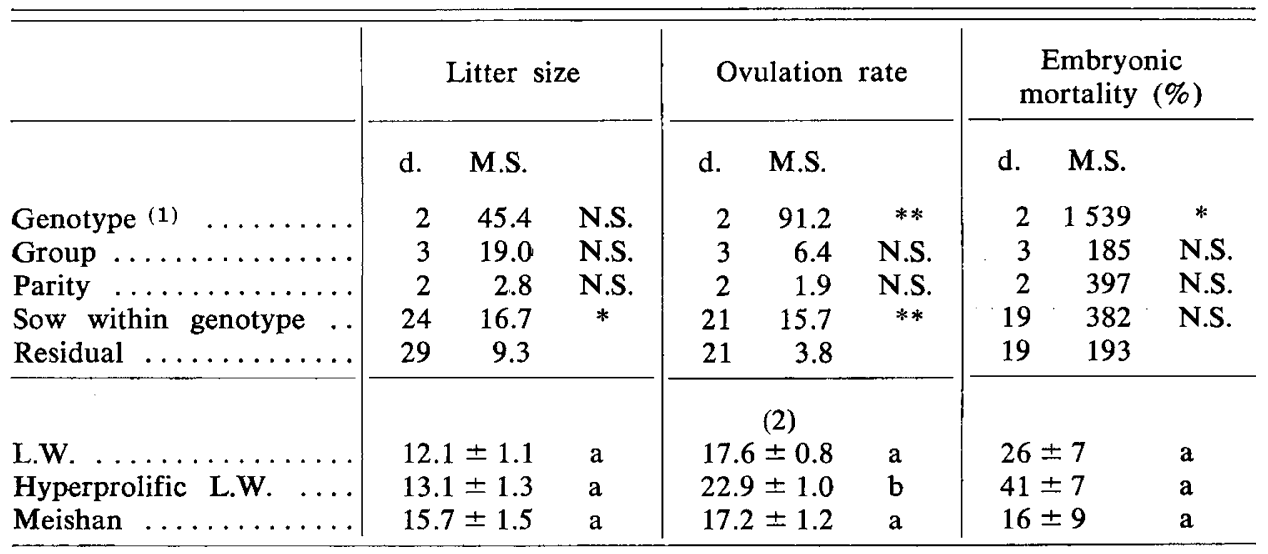

(1) F calculated with the sow within genotype M.S. as residual.

(2) In each column, figures with different letters are significantly different $(P<0.05)$.

N.S. : Not significant.

* : $\mathbf{P}<0.05$.

$* * \quad: \mathrm{P}<0.01$. 


\section{Relationship between ovulation and embryonic mortality rates}

In model (2), the effect associated with the within-genotype regression of embryonic mortality on ovulation rate was significant. The regression coefficient was significantly different from zero in HLW sows $(+3.4 \pm 0.9)$. It was not different from zero in $\mathrm{LW}(+1.9 \pm 1.4)$ and $\mathrm{MS}(+0.6 \pm 1.4)$ sows. But these coefficients were not significantly different between themselves. So we cannot conclude that there is a heterogeneity of regression slopes. So we used the model (3) ; the effects associated with genotype and covariable were significant $(F=2.6$ and 14.3 respectively). The slope of the regression was $2.5 \pm 0.7$ and the least squares estimates of embryonic mortality rate were respectively $32 \pm 4,34 \pm 4$ and $21 \pm 4$ for LW, HLW and MS sows, the last one being significantly different from both Large White groups $(\mathrm{P}<0.05)$.

\section{Comparison of gilts}

There was no difference between the 2 groups of Large White gilts for age at puberty, whereas that of MS gilts was very significantly lower ( $-140 \pm 12$ days) (table 4). The ovulation rate of MS gilts was significantly inferior to that of HLW and LW gilts at 1st and 3rd oestrus; the difference between LW and HLW gilts, in favor of the latter, was significant at the 3rd oestrus $( \pm 2.1 \pm 0.9, p<0.05)$ (table 4).

TABLE 4

Age at puberty and ovulation rate of gilts.

\begin{tabular}{|c|c|c|c|c|c|c|}
\hline & \multirow{2}{*}{\multicolumn{2}{|c|}{ Age at puberty }} & \multicolumn{4}{|c|}{ Ovulation rate } \\
\hline & & & \multicolumn{2}{|c|}{ 1st oestrus } & \multicolumn{2}{|c|}{ 3rd oestrus } \\
\hline & $\mathrm{n}$ & mean \pm s.d. & $\mathrm{n}$ & mean \pm s.d. & $\mathrm{n}$ & mean \pm s.d. \\
\hline L.W. & 15 & $227 \pm 9 \quad$ a & 15 & $13.7 \pm 0.7$ & 12 & $14.4 \pm 0.6$ \\
\hline Hyperprolific L.W. & 17 & $229 \pm 9 \quad$ a & 17 & $14.3 \pm 0.7$ & 13 & $16.5 \pm 0.6$ \\
\hline Meishan & 19 & $88 \pm 8 \quad b$ & 13 & $9.2 \pm 0.8$ & 15 & $11.7 \pm 0.6$ \\
\hline
\end{tabular}

In each column, figures with different letters are significantly different $(\mathbf{P}<0.05)$.

\section{Discussion}

A. Selection of hyperprolific sows in Large White herds

The HLW sows exhibited a superiority of 12.1 points over their contemporaries for the index of prolificacy, i.e. a genetic superiority of 1.21 piglets per litter. 
Assuming that they were all selected on the average of 3 litters, then it corresponds to a selection differential of 5.24 piglets. It is not possible to calculate the effective selection rate for the choice of these sows, but this selection differential corresponds approximately to a selection intensity of 2.95 , i.e. a selection rate of $0.4 \mathrm{p} .100$. The expected superiority of these HLW sows over their contemporaries in 4th parity is :

$$
S=\frac{n r}{1+(n-1) r}(X t-X c)
$$

where $\mathrm{n}=3 \mathrm{r}=0.15$ and $\mathrm{Xt}-\mathrm{Xc}=5.24$ so that $\mathrm{S}=1.81$.

This reduction of expected superiority after selection explains partly the reduction of litter size at the 4 th parity to 14.4 piglets (table 1 ).

\section{B. Comparison of the 3 genotypes}

The results have to be interpreted with caution because the number of data is low and the experimental design is note balanced (table 2). However, a preliminary analysis in which the genotype*parity interaction as added to model (1) did not show any significant interaction between genotype and parity $(F=0.20,0.20$ and 0.02 respectively for litter size, ovulation rate and embryonic mortality rate).

\section{Ovulation rate}

HLW adult sows differed from LW and MS by a high ovulation rate (+ 5.3 and 5.7). Daughters of hyperprolific parents also showed from the 3rd oestrus a superiority of 2.1 corpora lutea above control gilts. This superiority of the HLW gilts over the contemporary LW gilts was perfectly consistent with that of their mothers according to the heritability and repeatability of this trait, around 0.3 to 0.5 CunNingham et al., 1979 ; Legault \& GRUAND, 1981). These results confirm those already obtained with progeny of hyperprolific boars or sows (LEGAULT et al., 1981 ; BoleT \& LEgaulT, 1982). The repeatability of ovulation rate between 1st and 3rd oestrus, calculated with our data (table 4$)$ was $0.65(0.54,0.44$ and 0.43 respectively in LW, HLW and MS gilts). So, although the method of selection of HLW sows did not allow us to know their ovulation rate at puberty, we may suppose that it was already high. Conversely, the ovulation rate of adult MS sows was close to that of LW sows. This result is in good agreement with those of RombaUTs et al. (1982), but lower than those obtained in China by CHENG (1983). MS gilts were pubescent very young, as was observed by LEGAULT \& CARITEz (1983). Their ovulation rate observed at 1 st oestrus was lower than that of both groups of Large White gilts, but similar to that observed by CHENG (1983); it seemed to increase thereafter at a rate parallel to that of $\mathrm{HLW}$ gilts at the beginning, but did not exceed that of $\mathrm{LW}$ sows.

\section{Embryonic mortality rate and litter size}

The results obtained up to now on hyperprolific boar or sow daughters had shown an embryonic mortality rate which counterbalanced the increase of ovulation rate in primipares (LEGAULT et al., 1981), but not in multipares (BolET \& LEGAULT, 


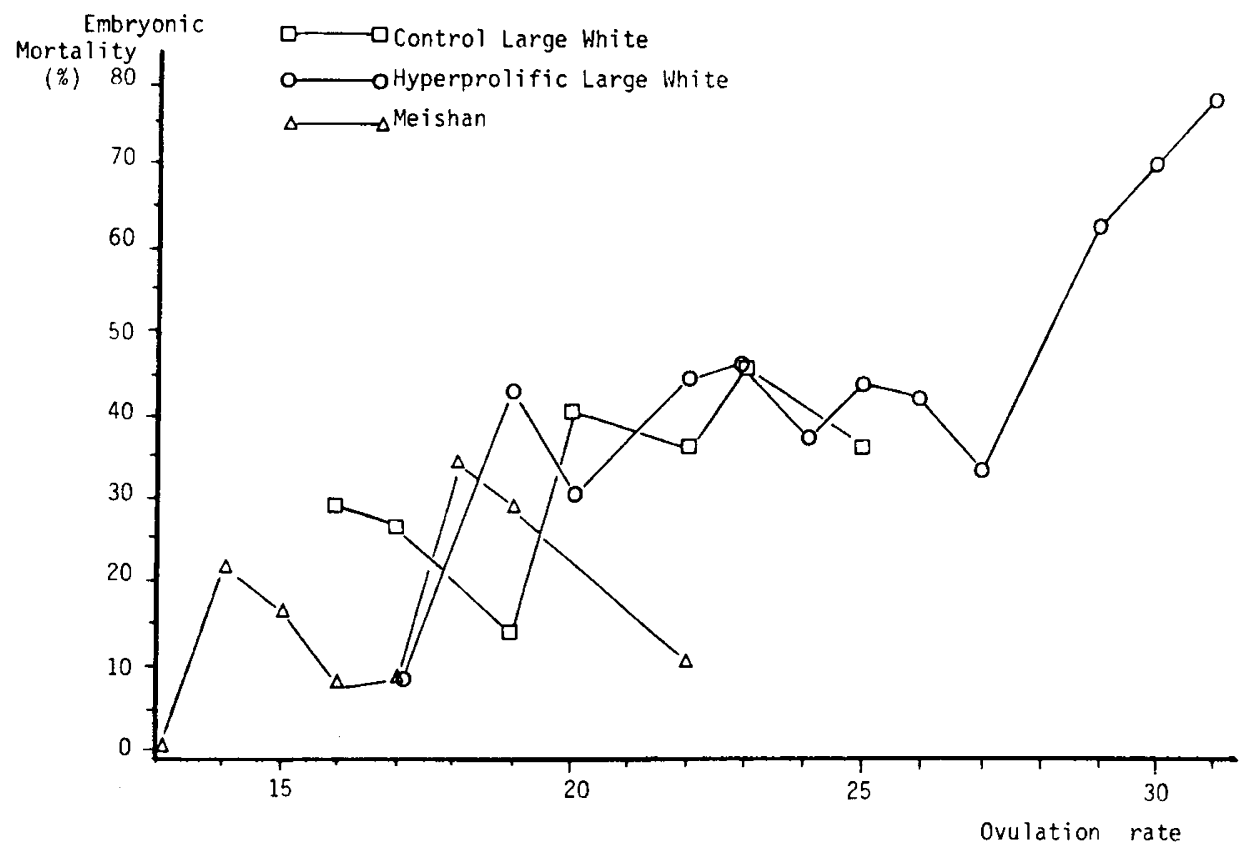

FIG. 1

Variation of the embryonic mortality rate according to the ovulation rate in the 3 genotypes.

1982 ; BolET, 1984). Our data only partially confirm these results, as the embryonic mortality rate was higher in HLW sow compared either to that LW sows or to the average value of $30 \mathrm{p} .100$ cited in the literature (BOLET, 1984). The positive relationship between embryonic mortality and ovulation rate is well known (BOLET, 1984) and confirmed by our results (figure 1). Although the regression of embryonic mortality on ovulation rate was significantly different from zero only for HLW sows, results of model (2) did not allow us to conclude that there was a heterogeneity of regression slopes between genotypes. The regression coefficient we calculated $(+2.5$ was similar to the value 2.1 obtained by KING \& Williams (1984). However, results of model (3) show that there was a significant effect of genotype on embryonic mortality, even when we included the ovulation rate as covariate. HLW and LW sows had a similar embryonic mortality rate (34 and $32 \mathrm{p} .100)$, whereas that of MS sows was significantly lower (21 p. 100). So, HLW sows are in fact Large White sows characterized by a high ovulation rate but the positive relationship between ovulation rate and embryonic mortality (figure 1) resulted in their prolificacy being only slightly higher than that of LW sows. Conversely, embryonic mortality of MS sows was low so that their litter size, although this result is not statistically significant, was superior by 3.6 piglets to that of LW sows; this observed prolificacy of MS sows is in good agreement with the results obtained in China (ZhANG et al., 1983) and in France (Legault \& CARITEz, 1983; Legault et al., 1984). However the comparison of embryonic mortality according to ovulation rate has to be interpreted with caution, because the distribution of ovulation differs widely between genotypes, 
especially between HLW and MS sows (figure 1). The main problem is to know whether we can combine the ovulatory capacity of the Large White breed, selected in the hyperprolific line, with the "gestational capacities " of Meishan sows.

\section{Conclusion}

Although the number of data is low, these results show clearly that the 2 prolific genotypes compared are characterized by a different balance between ovulation rate and embryo survival in the determination of their litter size. The hyperprolific sows are no more than Large White animals with high ovulation rate; the method of selection based on the whole population of Large White herds strongly improved the efficiency of selection compared to that achieved in closed herds (OLLIVIER \& BOLET, 1981 ; JOHNSON et al., 1984) as it resulted in this case in 2 additional ova in HLW daughters compared to LW daughters. But the extreme embryonic mortality rate of the adult hyperprolific sows may considerably limit the progress towards increased litter size at birth and their superiority over contemporary LW sows.

It may be concluded that to best utilise hyperprolific lines in European breeds, it is necessary to study ways of improving the embryo survival rate. The genetic determinism of this character is unknown (BOLET, 1984) but the results obtained in mice (BRADFORD, 1979) show that it is possible to increase it by genetic selection. For this purpose, the Meishan breed constitutes a new experimental model as it shows that there is a high variability between breeds for embryonic survival. So it should be possible to better analyse the genetic and physiological determinism of embryonic mortality and to improve the efficiency of genetic improvement of prolificacy by further comparing experimentally these 2 prolific genotypes, for example by crossbreeding, synthetic line formation or embryo transfer.

Received August 5, 1985.

Accepted February 13, 1986.

\section{Acknowledgements}

We wish to thank all the staff of the experimental station of pig selection (Rouille) and of the experimental hospital (Nouzilly) for their helpful participation in this experiment and Annick BOUROCHE for the revision of translation.

\section{References}

Bolet G., 1984. Timing and extent of embryonic mortality in pigs, sheep and goats. Genetic variability. E.E.C. Seminar, Brussels, December 11-12, 1984, SREENAN J.M., DiskIN M.G. (ed.), Embryonic mortality in farm animals, 12-43, Martinus Nijhoff Publishers, Brussels.

Bolet G., Legault C., 1982. New aspects of genetic improvement of prolificacy in pigs. 2nd World Congress on Genetics applied to Livestock production, Madrid, 4-8 octobre 19.82, 5, 548-567, Editorial Garsi, Madrid. 
BRADFORD G.E., 1979. Genetic variation in prenatal survival and litter size. J. Anim. Sci., supp. 15, 23-41.

Cheng P.L., 1983. A highly prolific pig breed of China. The Taihu pig. Pig News and Information, 4, 407-416.

Cunningham P.J., England M.E., Young L.D., Zimmerman D.W., 1979. Selection for ovulation rate in swine : correlated response in litter size and weight. J. Anim. Sci., 48, 509-516.

Johnson R.K., Zimmerman D.W., KitToK R.J., 1984. Selection for components of reproduction in swine. Livest. Prod. Sci., 11, 541-558.

KING R.H., Williams I.H., 1984. The influence of ovulation rate on subsequent litter size in sows. Theriogenology, 21, 677-680.

Legault C., Gruand J., 1976. Amélioration de la prolificité des truies par la création d'une lignée hyperprolifique et l'usage de l'insémination artificielle : principe et résultats expérimentaux préliminaires. $8^{\text {ss }}$ Journées de la Recherche porcine en France, Paris, 4-6 février 1976, 201-206, I.T.P., Paris.

Legault G., Owen J., 1976. Etablissement de facteurs de correction de la taille de portée pour l'âge de la mère à la mise-bas dans les races porcines françaises. $8^{e s}$ Journées de la Recherche porcine en France, Paris, 4-6 février 1976, 193-200, I.T.P., Paris.

Legault C., Gruand J., 1981. Effets additifs et non-additifs des gènes sur la précocité sexuelle, le taux d'ovulation et la mortalité embryonnaire chez la jeune truie. $13^{e s}$ Journées de la Recherche porcine en France, Paris, 4-5 février 1981, 247-254, I.T.P., Paris.

Legault C., Gruand J., Bolet G., 1981. Résultats de l'utilisation en race pure et en croisement d'une lignée dite «hyperprolifique ». $13^{e s}$ Journées de la Recherche porcine en France, Paris, 4-5 février 1981, 261-267, I.T.P., Paris.

Legault C., Caritez J.C., 1983. L'expérimentation sur le porc chinois en France. I. Performances de reproduction en race pure et en croisement. Génét. Sél. Evol., 15, 225-240.

Legault C., Caritez J.C., Gruand J., Bidanel J.P., 1984. Le point de l'expérimentation sur les races chinoises en France : "Reproduction» et «production》. $17^{e s}$ Journées de la Recherche porcine en France, Paris, 30 janvier-1 ${ }^{\text {er }}$ février 1984, 481-494, I.T.P., Paris.

Locatelli A., 1971. Technique d'examen coelioscopique des ovaires de la truie. Ann. Biol. Anim. Bioch. Biophys., 11, 495-498.

Ollivier L., Bolet G., 1981 La sélection sur la prolificité chez le porc : résultats d'une expérience de sélection sur dix générations. $13^{e s}$ Journées de la Recherche porcine en France, Paris, 4-5 février 1981, 261-267, I.T.P., Paris.

Rombauts P., Mazzari G., Dumesnil Dubuisson F., 1982. Premier bilan de l'expérimentation sur le porc chinois en France. 2 : estimation des composantes de la prolificité : taux d'ovulation et survie foetale. $14^{e s}$ Journées de la Recherche porcine en France, Paris, 3-4 février 1982, 137-142, I.T.P., Paris.

Zhang W.C., Wu J.S., Rempel W.E., 1983. Some performance characteristics of prolific breeds of pigs in China. Livest. Prod. Sci., 10, 59-68. 